Revista Brasileira de Farmacognosia Brazilian Journal of Pharmacognosy 22(4): 838-849, Jul./Aug. 2012

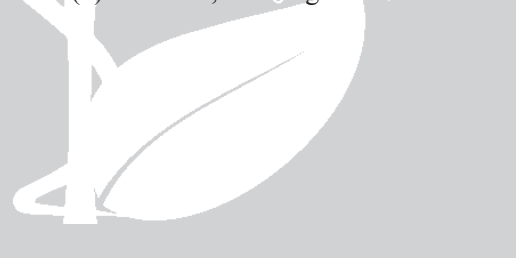

Article

Received 1 Nov 2011

Accepted 23 Dec 2011

Available online 29 May 2012

Keywords:

Laurencia complex

Laurencia oliveirana

molecular phylogeny

$r b c \mathrm{~L}$

seaweed

taxonomy

ISSN 0102-695X

http://dx.doi.org/10.1590/S0102-

695X2012005000070

\section{Morphological and molecular studies on the Brazilian native red seaweed Laurencia oliveirana (Rhodomelaceae, Ceramiales)}

\author{
Valéria Cassano, ${ }^{*}$, Mariana C. Oliveira, ${ }^{1}$ Ma. Candelaria Gil- \\ Rodríguez, ${ }^{2}$ Abel Sentíes, ${ }^{3}$ Jhoana Díaz-Larrea, ${ }^{3}$ Mutue T. \\ Fujii $^{4}$
}

\author{
${ }^{1}$ Departamento de Botânica, Universidade de São Paulo, Brazil, \\ ${ }^{2}$ Departamento de Biología Vegetal (Botánica), Universidad de La Laguna, Spain, \\ ${ }^{3}$ Departamento de Hidrobiología, Universidad Autónoma Metropolitana, Iztapalapa, \\ Mexico, \\ ${ }^{4}$ Núcleo de Pesquisa em Ficologia, Instituto de Botânica, São Paulo, Brazil.
}

\begin{abstract}
Morphological and molecular studies were carried out on Laurencia oliveirana from the type locality (Arraial do Cabo, Rio de Janeiro, Brazil). This species is easily recognized by its small size, sub-erect habit forming intricate cushion-like tufts and unilateral pectinate branching. The species displays all the typical characters of the genus Laurencia, such as the production of the first pericentral cell underneath the basal cell of the trichoblast, tetrasporangia produced from particular pericentral cells, with the third and fourth pericentral cells becoming fertile, without production of additional pericentral cells, spermatangial branches produced from one of two laterals on the suprabasal cell of trichoblasts, and procarp-bearing segment with five pericentral cells. Details of tetrasporangial plants and development of procarp and male plants are described for the first time for the species. The phylogenetic position of L. oliveirana was inferred by analysis of the chloroplast-encoded $r b c \mathrm{~L}$ gene sequences from 57 taxa. In all phylogenetic analyses, L. oliveirana grouped with $L$. caraibica, L. caduciramulosa, $L$. venusta and L. natalensis, forming a monophyletic clade within the Laurencia sensu stricto. The genetic divergence between L. oliveirana and the molecularly closest species, L. caraiba collected in Brazil, was $2.3 \%$.
\end{abstract}

\section{Introduction}

Currently, the Laurencia complex comprises five genera: Laurencia J.V. Lamouroux, Osmundea Stackhouse, Chondrophycus (Tokida \& Saito) Garbary \& J.T. Harper, Palisada (Yamada) K.W. Nam and Yuzurua (K.W. Nam) Martin-Lescanne. Laurencia oliveirana Yoneshigue possesses all the characters typical of the genus Laurencia s.s., such as: production of the first pericentral cell underneath the basal cell of the trichoblast, production of tetrasporangia from a particular pericentral cell, without production of additional pericentral cells, spermatangial branches produced from one of two laterals on the suprabasal cell of trichoblasts, and the procarpbearing segment with five pericentral cells.

Laurencia oliveirana was proposed by Yoneshigue (1985) from the upwelling region of Arraial do Cabo, Rio de Janeiro. Later, Fujii (1990) reported this species for Ubatuba, northern coast of São Paulo state, and confirmed, by analysis of herbarium material, that the taxon previously named as Laurencia sp. by Joly (1965), collected in Bertioga and Ubatuba, São Paulo and Parati, Rio de Janeiro, corresponded to L. oliveirana. According to Fujii \& Villaça (2003), the Laurencia sp. described by Baptista (1977) for the flora of Torres, Rio Grande do Sul, also corresponds to L. oliveirana. On the Rio de Janeiro coast, besides the type locality, the species was reported for Ilha Grande, Angra dos Reis by Gestinari et al. (1998). The geographical distribution of this species was expanded by Nunes (1998), who reported it on the coast of Bahia. Later, Horta (2000) and Amado Filho et al. (2006) reported it for the Laje de Santos Marine State Park and Queimada Grande Island, São Paulo, at a depth of $22 \mathrm{~m}$. Although Wynne (2011) cited a record of L. oliveirana from Cuba by Areces et al. (2003), the Note "204" was a typo for 203, namely the account by Fujii \& Sentíes (2005) of this species from Brazil (Wynne, pers. comm.). Therefore, so far, the occurrence of $L$. oliveirana can be considered to be restricted to the Brazilian coast.

Within the Laurencia complex, the genus Laurencia s.s. has been highlighted as an important synthesizer of halogenated secondary metabolites, 
especially terpenes (Erickson, 1983; Pereira \& Teixeira, 1999), with proven antifouling activity (Da Gama et al., 2002; Cassano et al., 2008) and pharmacological importance, as recently compiled by Fujii et al. (2011) for the Brazilian species. The typical Laurencia s.s. species possess refractile inclusions named corps en cerise, mainly in cortical cells of the thallus, which are the sites of production and /or accumulation of halogenated metabolites (Howard et al., 1980; Young et al., 1980; Salgado et al., 2008). Corps en cerise, in number of 1-2 (3) per cortical cell, are cited in the original description of L. oliveirana made by Yoneshigue (1985). The presence of corps en cerise in L. oliveirana makes it a potential producer of secondary metabolites that still need to be investigated.

This study describes and illustrates, in detail, morphological characters of Laurencia oliveirana, comparing it with related species, and also infers its phylogenetic position using the chloroplast-encoded $r b c \mathrm{~L}$ gene, confirming its taxonomical position at the species level. Details of tetrasporangial plants and development of the procarp and male plants are described for the first time for this species.

\section{Materials and Methods}

\section{Morphological observations}

Samples of Laurencia oliveirana were collected from the type locality, Ponta da Cabeça, Arraial do Cabo, Rio de Janeiro, Brazil, in 2008. Voucher specimens and material for morphological study were fixed in $4 \%$ formalin/ seawater or pressed as herbarium sheets. Transverse and longitudinal hand-sections were made with a stainlesssteel razor blade and stained with $0.5 \%$ aqueous aniline blue solution, acidified with $1 \mathrm{~N} \mathrm{HCl}$ (Tsuda \& Abbott, 1985). Living specimens were also examined to check for the presence of corps en cerise. Measurements are given as length $\mathrm{x}$ diameter. For comparison purposes, additional specimens provided by the Herbarium of the Department of Botany, University of São Paulo (SPF-Algae), and by the Herbarium of the Botanical Institute (SP) were analyzed. Line-drawings were prepared using a camera lucida mounted on a Nikon Eclipse E200 microscope (Tokyo, Japan) and photomicrographs were taken with a Sony W5 digital camera (Tokyo, Japan) coupled to a Nikon microscope. Vouchers are deposited in the SP and SPF herbaria. Herbarium abbreviations follow the online Index Herbariorum (http://www.nybg.org/bsci/ih/ih.html).

\section{Molecular analyses}

Samples used for molecular analysis were dried in silica gel. Total DNA was extracted, after grinding in liquid nitrogen, using the DNeasy Plant
Mini Kit (Qiagen, Valencia, CA, USA) following the manufacturer's instructions. A total of $57 \mathrm{rbcL}$ sequences were used in this study (Table 1). For each sequence generated, a total of 1467 base pairs of the $r b c \mathrm{~L}$ gene were amplified in three overlapping parts with the primers pairs: FrbcLstart-R753a, F492aR1150a and F993-RrbcS (Freshwater \& Rueness, 1994; Cassano 2009) using PCR master mix (Promega Corp., Madison, WI, USA). All PCR products were analyzed by electrophoresis in $1 \%$ agarose to check product size. The PCR products were purified with the MicroSpin $^{\mathrm{TM}}$ S-300 HR Columns (GE Healthcare Life Sciences, Piscataway, USA) in accordance with the manufacturer's instructions. Sequencing was carried out with the BigDye Terminator Cycle Sequencing Reaction Kit (Applied Biosystems, NJ, USA) on an ABI PRISM 3100 Genetic Analyzer (Applied Biosystems). The primers used for the sequencing were those used for the PCR amplification. The full sequence was obtained from both DNA strands. Multiple alignments for $r b c \mathrm{~L}$ sequences were constructed using the computer program BioEdit 7.0.4.1 (Hall, 1999).

\section{Phylogenetic analyses}

Phylogenetic relationships were inferred with PAUP 4.0b10 (Swofford, 2002) and MrBayes v.3.0 beta 4 (Huelsenbeck \& Ronquist, 2001). Maximumparsimony trees (MP) were constructed using the heuristic search option, tree-bisection-reconnection branch swapping, unordered and unweighted characters. Support values for the relationships discovered in each analysis were calculated by performing bootstrap analyses (Felsenstein, 1985), as implemented in PAUP. Ten thousand heuristic search replicates were executed using the TBR branch-swapping algorithm. The model used in the Bayesian analysis was the generaltime-reversible model of nucleotide substitution with invariant sites and gamma distributed rates for the variable sites $(\mathrm{GTR}+\mathrm{I}+\mathrm{G})$. This model was selected based on maximum likelihood ratio tests implemented by the software Modeltest version 3.06 (Posada \& Crandall, 1998) with a significance level of 0.01 by Akaike information criterion. For the Bayesian analysis, four chains of the Markov chain Monte Carlo (one hot and three cold) were used, sampling one tree every 10 generations for 1,000,000 generations starting with a random tree. Log-likelihood values were stabilized around 50,000 generations, which were discarded as 'burn in'. A 50\% consensus tree (majority rule as implemented by PAUP) was computed after the 'burn in' point. The range of $r b c \mathrm{~L}$ divergence values within and among species was calculated using uncorrected ' $p$ ' distances using PAUP. 
Morphological and molecular studies on the Brazilian native red seaweed Laurencia oliveirana (Rhodomelaceae, Ceramiales)

Table 1. Taxa used in this study for phylogenetic analysis.

\begin{tabular}{|c|c|c|}
\hline Samples & Collection data & $\begin{array}{c}\text { GenBank } \\
\text { accession numbers }\end{array}$ \\
\hline $\begin{array}{l}\text { Bostrychia radicans (Montagne) } \\
\text { Montagne in Orbigny }\end{array}$ & USA, Mississippi, St. Louis Bay, 11 Feb. 1998, C.F.D. Gurgel & AF259497 \\
\hline Polysiphonia muelleriana J. Agardh & $\begin{array}{l}\text { New Zealand, Deas Cove, Thompson Sound, Fiordland, } 03 \text { Oct. 2000, } \\
\text { S. Wing and N. Goebel }\end{array}$ & AY588412 \\
\hline Bryocladia cuspidata (J. Agardh) De Toni & $\begin{array}{l}\text { USA, Texas, Port Aransas, } 17 \text { May 1998, S. Fredericq and C.F.D. } \\
\text { Gurgel }\end{array}$ & AF259498 \\
\hline Chondria collinsiana M.A. Howe & $\begin{array}{l}\text { Brazil, Rio de Janeiro, Armação dos Búzios, Praia Rasa, } 13 \text { Jan. 2005, } \\
\text { V. Cassano and J.C. De-Paula }\end{array}$ & GU330225 \\
\hline C. cf undulatus & New Caledonia, Loyalty Is., Maré, 22 Mar. 2005, C. Payri & FJ785307 \\
\hline Chondrophycus sp. 1 & New Caledonia, Loyalty Is., Lifou, 26 Mar. 2005, C. Payri & FJ785309 \\
\hline Chondrophycus sp. 2 & New Caledonia, Loyalty Is., Maré, 21 Mar. 2005, C. Payri & FJ785310 \\
\hline Chondrophycus sp. 3 & $\begin{array}{l}\text { New Caledonia, Loyalty Is., Beautemps/ Beaupré, } 06 \text { Apr. 2005, C. } \\
\text { Payri }\end{array}$ & FJ785311 \\
\hline Laurencia aldingensis Saito \& Womersley & $\begin{array}{l}\text { Brazil, Rio de Janeiro, Armação dos Búzios, Praia Rasa, RJ, 13. Jan. } \\
\text { 2005, V. Cassano and J.C. De-Paula }\end{array}$ & JF810351 \\
\hline L. cf. brongniartii & Australia, Tarcoala Beach, 1993, S. Fredericq & EF061654 \\
\hline L. cf. brongniartii & Taiwan, Makang Harbour, 11 Jul. 1993, S. Fredericq & AF465814 \\
\hline L. caduciramulosa Masuda \& Kawaguchi & $\begin{array}{l}\text { Brazil, Rio de Janeiro, Angra dos Reis, Baía da Ribeira, Praia do Velho, } \\
19 \text { Apr. 2006, V. Cassano and J.C. De-Paula }\end{array}$ & - \\
\hline L. caraibica P.C. Silva & $\begin{array}{l}\text { Mexico, Quintana Roo, Cancún, Isla Mujeres, } 23 \text { Feb. 2006, A. } \\
\text { Sentíes }\end{array}$ & EF658642 \\
\hline L. caraibica & Brazil, Rio Grande do Norte, Atol das Rocas, 07 Jul. 2002, R. Villaça & - \\
\hline L. catarinensis Cordeiro-Marino \& M.T. Fujii & $\begin{array}{l}\text { Brazil, Espírito Santo, Anchieta, Ponta dos Castelhanos, } 05 \text { Oct. 2006, } \\
\text { M.T. Fujii and V. Cassano }\end{array}$ & - \\
\hline $\begin{array}{l}\text { Laurencia dendroidea J. Agardh } \\
\text { [as L. filiformis (C. Agardh) Montagne] }\end{array}$ & $\begin{array}{l}\text { Brazil, Bahia, Lauro de Freitas, Praia Vilas do Atlântico, } 08 \text { Jan. 2008, } \\
\text { A. Oliveira }\end{array}$ & GU330228 \\
\hline $\begin{array}{l}\text { L. dendroidea [as L. majuscula (Harvey) A.H.S. } \\
\text { Lucas] }\end{array}$ & $\begin{array}{l}\text { Brazil, Rio de Janeiro, Angra dos Reis, Praia do Velho, } 20 \text { Jul. 2006, V. } \\
\text { Cassano and J.C. De-Paula }\end{array}$ & GU330232 \\
\hline L. flexuosa Kützing & $\begin{array}{l}\text { South Africa, S. KwaZulu-Natal, Palm Beach, } 07 \text { Feb. 2001, S. } \\
\text { Fredericq }\end{array}$ & AF465815 \\
\hline L. intricata J.V. Lamouroux & Mexico, Yucatan, Campeche Bay, 14 Feb. 1999, C.F.D. Gurgel & AF465809 \\
\hline L. intricata & $\begin{array}{l}\text { USA, Florida, Long Key, Channel 5, } 10 \text { Dec. 1998, B. Wysor and T. } \\
\text { Frankovich }\end{array}$ & AY588410 \\
\hline L. intricata & Cuba, Ciego de Ávila, Cayo Coco, 25 Sep. 2005, M.T. Fujii & GU330238 \\
\hline L. cf. kuetzingii & New Caledonia, Loyalty Is., Ouvéa, 31 Mar. 2005, C. Payri & FJ785322 \\
\hline L. cf. mariannensis & $\begin{array}{l}\text { New Caledonia, Lagon Sud-Ouest, Ilot Larégnère, } 11 \text { Jul. 2003, C. } \\
\text { Payri }\end{array}$ & FJ785313 \\
\hline $\begin{array}{l}\text { L. marilzae Gil-Rodríguez, Sentíes, Cassano, } \\
\text { Díaz-Larrea \& M.T. Fujii }\end{array}$ & $\begin{array}{l}\text { Spain, Canary Islands, Tenerife, Playa Paraíso, } 14 \text { Jul. 2006, M.C. Gil- } \\
\text { Rodríguez, M.T. Fujii and A. Sentíes }\end{array}$ & EF686001 \\
\hline L. marilzae & $\begin{array}{l}\text { Spain, Canary Islands, Tenerife, Punta del Hidalgo, } 12 \text { Jul. 2006, M.C. } \\
\text { Gil-Rodríguez, }\end{array}$ & EF686002 \\
\hline L. marilzae & $\begin{array}{l}\text { Brazil, São Paulo, Laje de Santos Marine State Park, Parcel do Sul, } 25 \\
\text { Mar. 2007, R. Rocha-Jorge }\end{array}$ & GU938189 \\
\hline L. cf. mcdermidiae & New Caledonia, Ile des Pins, 29 Nov. 2005, C. Payri & FJ785314 \\
\hline L. natalensis Kylin & South Africa, KwaZulu-Natal, Palm Beach, 07 Feb. 2001, S. Fredericq & AF465816 \\
\hline L. cf. nidifica & New Caledonia, Ile des Pins, 30 Nov. 2005, C. Payri & FJ785315 \\
\hline L. obtusa (Hudson) J.V. Lamouroux & Ireland, County Donegal, Fanad Head, 06 Jul. 1998, C.A. Maggs & AF281881 \\
\hline L. oliveirana Yoneshigue & $\begin{array}{l}\text { Brazil, Rio de Janeiro, Arraial do Cabo, Ponta da Cabeça, } 07 \text { Jul. 2008, } \\
\text { V. Cassano and J.C. De-Paula }\end{array}$ & JF810352 \\
\hline L. pyramidalis Bory ex Kützing & France, Brittany, Roscoff, 05 Dec. 2002, F. Rousseau & FJ785316 \\
\hline L. translucida M.T. Fujii \& Cordeiro-Marino & Brazil, Espírito Santo, Marataízes, 15 Sep. 2001, M.T. Fujii & AY588408 \\
\hline
\end{tabular}


L. venusta Yamada

L. viridis Gil-Rodríguez \& Haroun

Laurencia sp.

Osmundea blinksii (Hollenberg \& Abbott) K.W. Nam

O. oederi (Gunnerus) G. Furnari [as $O$. ramosissima (Oeder) Athanasiadis]

O. osmunda (S.G. Gmelin) K.W. Nam

O. pinnatifida (Hudson) Stackhouse

O. sinicola (Setchell \& Gardner) K.W. Nam

O. spectabilis (Postels \& Ruprecht) K.W. Nam var. spectabilis

O. splendens (Hollenberg) K.W. Nam

O. truncata (Kützing) K.W. Nam \& Maggs

Palisada corallopsis (Montagne) Sentíes, M.T. Fujii \& Díaz-Larrea

P. flagellifera (J. Agardh) K.W. Nam

P. flagellifera

Palisada furcata (Cordeiro-Marino \& M.T. Fujii) Cassano \& M.T. Fujii

P. patentiramea (Montagne) Cassano, Sentíes, Gil-Rodríguez \& M.T. Fujii

P. perforata (Bory) K.W. Nam

P. perforata

P. perforata

Palisada. cf. robusta

Palisada cf. cruciata

P. thuyoides (Kützing) Cassano, Sentíes, GilRodríguez \& M.T. Fujii

Yuzurua poiteaui (J.V. Lamouroux) MartinLescanne var. poiteaui

Y. poiteaui var. poiteaui
Mexico, Quintana Roo, Puerto Morelos, Punta Brava, 18 Apr. 2004, J. Díaz-Larrea and A. Sentíes

Spain, Canary Islands, Tenerife, Punta del Hidalgo, Roca Negra, 06 Oct. 2005, M.C. Gil-Rodríguez

Brazil, Rio de Janeiro, Armação dos Búzios, Praia Rasa, 13 Jan. 2005, V. Cassano and J.C. De-Paula

USA, California, San Mateo Co., Año Nuevo, Greyhound Rock, 17 Jul. 1996, M.H. Hommersand

Ireland, Co. Donegal, St. John's Point, 12 Oct. 1999, C.A. Maggs

Ireland, County Donegal, St. John's Point, 12 Oct. 1999, C.A. Maggs

France, Brittany, Penmarch

USA, California, Orange Co., Crescent Beach, 28 May 2002, S. Murray

Mexico, Baja California, Punta Santo Thomas, 2 Jul. 1996, M.H. Hommersand

Mexico, Baja California, Bahia Colnett, Drift, 2 Jul. 1996, M.H. Hommersand and J. Hughey

Ireland, Lough Hyne, Co. Cork, 11 Nov. 1999, C.A. Maggs

EF061655

EF685999

Mexico, Quintana Roo, Cancún, Chaac-Mol Beach, 21 Aug. 2005, J. Díaz-Larrea and A. Sentíes

Brazil, Rio de Janeiro, Rio das Ostras, Areias Negras, 03 Aug. 2005, V. Cassano and M.B. Barros-Barreto

Brazil, São Paulo, Ubatuba, Praia Brava, 25 May 2001, S.M.B. Guimarães and J. Domingos

Brazil, Paraíba, Praia de Tambaú, 24 Feb. 2004, M.T. Fujii

AY 172575

AF281880

AF281877

AF259495

AY 588407

AY172574

AY172576

AF281879

EF061646

GU330221

AF465804

GU330226

Philippines

AF489862

Spain, Canary Islands, Tenerife, Pto. de La Cruz, San Telmo, 14 Jul. 2006, M.C. Gil-Rodríguez, M.T. Fujii and A. Sentíes

Mexico, Quintana Roo, Cancún, Isla Mujeres, 2 Mar. 2007, A. Sentíes and M.C. Gil-Rodríguez

Brazil, Rio de Janeiro, Parati, Praia Vermelha, 30 Dec. 2005, V. Cassano

New Caledonia, Lifou, 23 Mar. 2005, C. Payri

New Caledonia, Ils des Pins, 04 Dec. 2005, C. Payri

Philippines

FJ785319

AF489863

USA, Florida, Long Key, Ocean Side, 1998, S. Fredericq

EF061652

Mexico, Quintana Roo, Playa del Carmen, 15 Mar 2005, J. Díaz-Larrea and A. Sentíes

\section{Results}

\section{Morphological study}

Laurencia oliveirana Yoneshigue, Taxonomie et ecologie des algues marines dans la region de Cabo Frio (Rio de Janeiro) Brésil, Université d'Aix-Marseille. 1985: 329-330 (Figures 1-23).

Holotype: YY 4016 in Phycological Herbarium, Instituto Nacional de Estudos do Mar, Arraial do Cabo,
Rio de Janeiro, Brazil.

Isotype: SPF 24767!

Type locality: Ponta da Cabeça, Arraial do Cabo, Rio de Janeiro, Brazil

Plants with sub-erect habit forming brownreddish to brown-greenish intricate cushion-like tufts, up to $1.5 \mathrm{~cm}$ high (Figures 1-4). The thalli are terete, fleshy in texture, adhering to herbarium paper when dried. Main sub-erect axes with indeterminate growth 
$175-300 \mu \mathrm{m}$ in diameter, attached to the substratum by small discoid holdfasts (Figure 4), from which arise erect axes with determinate growth $270-580 \mu \mathrm{m}$ in diameter in the middle portions of the thalli. The terete axes are sparsely branched. Branching is unilateral pectinate to alternate-distichous with one order of branches. Ultimate branchlets are cylindrical to clavate, simple, long or short with (160) 250-700 (1000) x 130 350 (575) $\mu \mathrm{m}$.

In surface view, cortical cells are regularly arranged throughout the thalli in longitudinal rows and connected to each other by longitudinally oriented secondary pit connections (Figure 5), with only one corp en cerise per cell (Figure 6) and one per trichoblast cell. Cortical cells in surface view are isodiametricpolygonal in the lower and in the upper portions of the thalli and elongate-polygonal in the middle portions, (22.5) 52.5-77.5 (87.5) x 22.5-40 $\mu \mathrm{m}$. In median longitudinal section through a branchlet, outer cortical cell walls near apices are not projected beyond the surface (Figure 7).

In transverse section, thalli present one or two layers of pigmented cortical cells and three or four layers of colorless medullary cells (Figure 8). Cortical cells in transverse section are quadratic to cuneiform, neither radially elongated nor arranged as a palisade, $20-32.5 \times 25-40 \mu \mathrm{m}$ in the middle portions of the thalli. Medullary cells are rounded or slightly radially elongated, becoming larger toward the thallus center, $40-105 \mu \mathrm{m} \times 37.5-82.5 \mu \mathrm{m}$ in the middle portions of the thalli. Lenticular thickenings are occasionally present. When present, they occur in medullary cell walls of main axes or lateral branches and especially at the bases of cystocarps (Figures 9 and 19). Each vegetative axial segment cuts off four pericentral cells (Figure 10). The first pericentral cell is produced underneath the basal cell of the trichoblast.

Male plants with clavate tip branches, characteristically swollen, simple, 780-1125 $\mu \mathrm{m}$ in diameter (Figure 3). In longitudinal section through a fertile branchlet, the spermatangial pits are cup-shaped, and an axial cell row is discernible at the base (Figure 11). Spermatangial trichoblasts arise from the axial cell, consisting of fertile and sterile branches (Figure 12); the fertile branches produce many ovoid spermatangia, 7.5-10 x 2.5-5 $\mu \mathrm{m}$, and terminate in vesicular sterile cells, 17.5-27.5 $\mu \mathrm{m} \times 12.5-20 \mu \mathrm{m}$ (Figure 13); each spermatium possesses an apical nucleus (Figure 12).

In the female plants, each procarp-bearing segment produces five pericentral cells (Figure 14), the fifth of which becomes the supporting cell of a four-celled carpogonial branch with two groups of sterile cells (basal and lateral), which develop from the supporting cell of the carpogonial branch (Figures 1517). After fertilization, the supporting cell cut off its distal end, producing the auxiliary cell. Gonimoblast filaments produce many carposporangia terminally, which are clavate to cuneiform-elongate, 90-147.5 x 30-52.5 $\mu \mathrm{m}$. Fully developed cystocarps are pyriform, prominent and without a protuberant ostiole, arranged along the upper third to subapical portions of the thallus, 580-750 $\mu \mathrm{m}$ in diameter (Figures 2 and 18).

Tetrasporangial plants with cylindrical and simple branchlets, 1425-8000 x 325-550 $\mu \mathrm{m}$ (Figures 4 and 20). At the apex of fertile branches, each axial segment produces two fertile pericentral cells, the third and the fourth ones (Figure 21); the first and the second pericentral cells remain sterile. Each fertile pericentral cell cuts off two pre-sporangial cover cells distally and abaxially the tetrasporangial initial. Subsequently, one post-sporangial cover cell is produced (Figure 22) and continues dividing and contributes to produce cortication around the tetrasporangium. The pre-sporangial cover cells do not divide and display a transverse-type alignment in relation to the fertile axis in surface view. Tetrasporangial maturation is in a clockwise spiral, and the final arrangement is a parallel pattern in relation to fertile branchlets (Figure 23). Mature tetrasporangia are tetrahedrally divided, 50-85 $\mu \mathrm{m}$ in diameter.

The epilithic specimens were collected from the intertidal zone at exposed wave-action sites, associated with turfs of articulated Corallinaceae. In this study, L. oliveirana was found in the type locality only in winter.

\section{Geographical distribution}

Atlantic Ocean, Brazil, Northeastern: Bahia (Nunes, 1998); Southeastern: Rio de Janeiro (Yoneshigue, 1985; Gestinari et al., 1998; Cassano 2009), São Paulo (Joly, 1965, as Laurencia sp.; Horta, 2000; Fujii and Sentíes, 2005; Amado Filho et al., 2006); South: Rio Grande do Sul (Baptista, 1977, as Laurencia sp.).

\section{Examined material}

Isotype: Laurencia oliveirana Yoneshigue ['Laurencia oliverae']: BRAZIL: Rio de Janeiro: Arraial do Cabo, Ponta da Cabeça, tetrasporangial plant, 25.viii.1983, Y. Yoneshigue YY4016 (SPF24767), 07.vii.2008, female, male and tetrasporangial plants, V. Cassano and J.C. DePaula (SP399.857), Parati, Praia de Panema, 12.v.1963, tetrasporangial plant, A.B. Joly, E.C. Oliveira, M. CordeiroMarino, N. Yamaguishi and Y. Ugadim (SPF55393), São Paulo: Picinguaba, Praia Brava, 20.vii.1989, M.T.Fujii and M.N. Fujii, Bertioga, between Praia Preta and Prainha, 08.vi.1963, E.C. Oliveira, M. Cordeiro-Marino, N. Yamaguishi and Y. Ugadim (SPF028230), Ubatuba, Praia de Fora, 21.vii.1963, A.B. Joly, E.C. Oliveira, M. Cordeiro- 

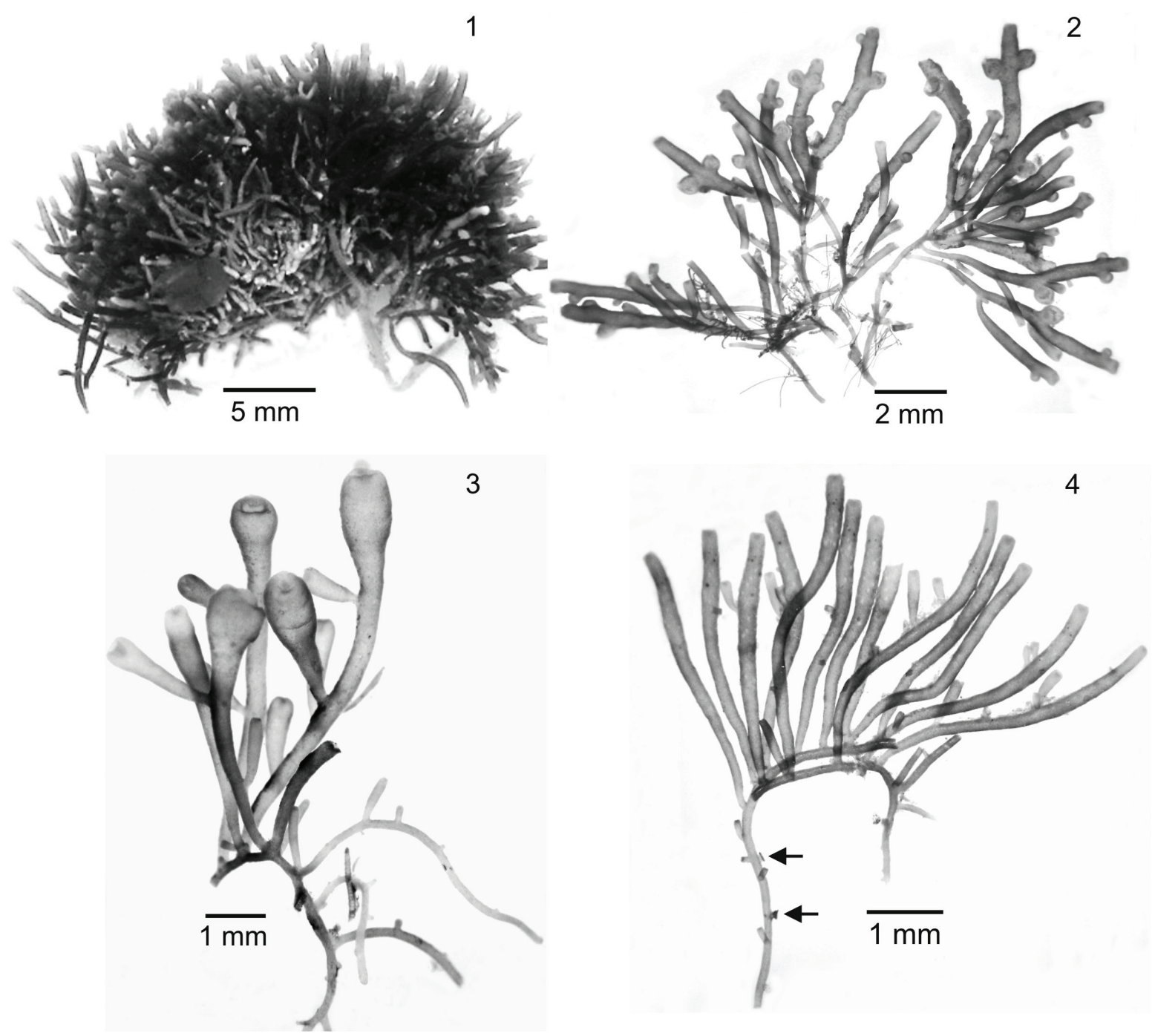

Figures 1-4. Habit of Laurencia oliveirana. 1. Aspect of an intricate tuft associated with articulated Corallinaceae. 2. Female plant. 3. Male plant. 4. Tetrasporangial plant. Note basal portion with discoid holdfasts (arrows).

Marino, N. Yamaguishi and Y. Ugadim (SPF24756), Ilha das Couves, 22.vii.1963, tetrasporangial plant, A.B. Joly, E.C. Oliveira, M. Cordeiro-Marino, N. Yamaguishi and Y. Ugadim (SPF24757), Praia do Bonete, 19.viii.1963, tetrasporangial plant, A.B. Joly, E.C. Oliveira, M. CordeiroMarino, N. Yamaguishi and Y. Ugadim (SPF026565), Ilha Anchieta, Praia do Sul, 18.viii.1963, A.B. Joly, E.C. Oliveira, M. Cordeiro-Marino, N. Yamaguishi and Y. Ugadim (SPF24760).

Additional examined materials for other taxa: Laurencia caraibica: Atol das Rocas, 07.vii.2002, R. Villaça (SP399940).

\section{Molecular study}

In this study, a total of 57 sequences were analyzed, including members of the Ceramiales Bostrychia radicans (Montagne) Montagne, Bryocladia cuspidata (J.
Agardh) De Toni, Chondria collinsiana M. A. Howe and Polysiphonia muelleriana J. Agardh as outgroups (Table 1). In all $r b c \mathrm{~L}$ sequences, a total of 250 nucleotides were removed from the beginning and/or end of the sequences since many sequences from the GenBank were incomplete, producing a data set of 1217 base pairs. The data set consisted of 738 constant characters, 399 parsimonyinformative sites and 80 parsimony non-informative sites. The analyses show that the Laurencia complex is monophyletic and it was separated into the five clades currently accepted as different genera (Figure 24).

In all phylogenetic analyses, L. oliveirana positioned within the Laurencia sensu stricto forming a monophyletic clade with $L$. caraibica P.C. Silva, $L$. caduciramulosa Masuda \& Kawaguchi, L. venusta Yamada and L. natalensis Kylin with high support to posterior probability (100\%). Laurencia oliveirana grouped in all analyses with L. caraibica from Brazil, 

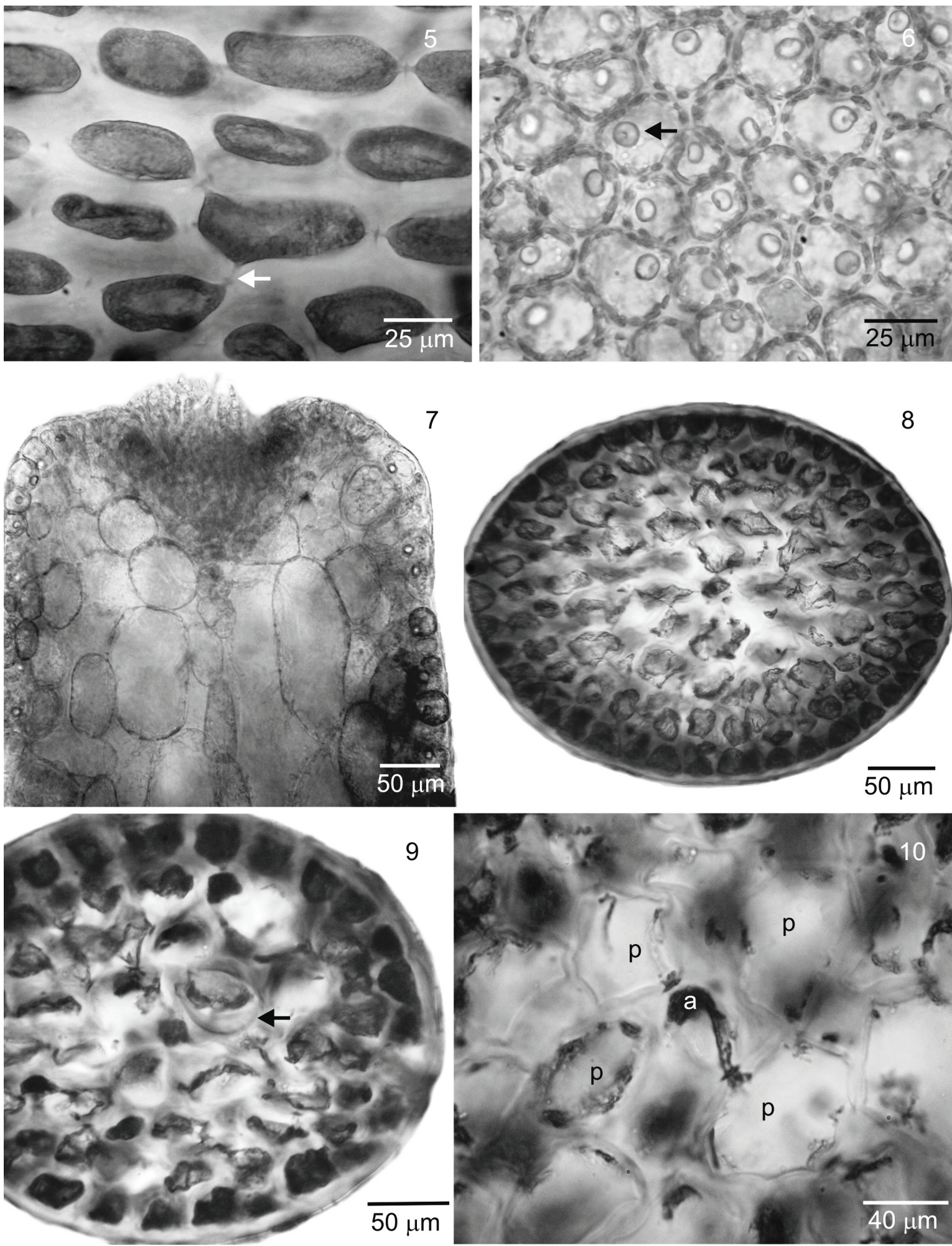

Figures 5-10. Vegetative characters. 5. Cortical cells in surface view of middle portion of the thallus showing secondary pitconnections (arrow). 6. Cortical cells in surface view, showing one corp en cerise per cell in living material (arrow). 7. Longitudinal section through a branchlet showing non-projecting cortical cells. Note corps en cerise in cortical cells in living material. 8. Transverse section of the thallus showing two layers of pigmented cortical cells and three layers of colorless medullary cells. 9. Transverse section showing lenticular thickening in pericentral cell (arrow). 10. Transverse section of the upper portion of a branch showing an axial cell (a) with four pericentral cells (p). 


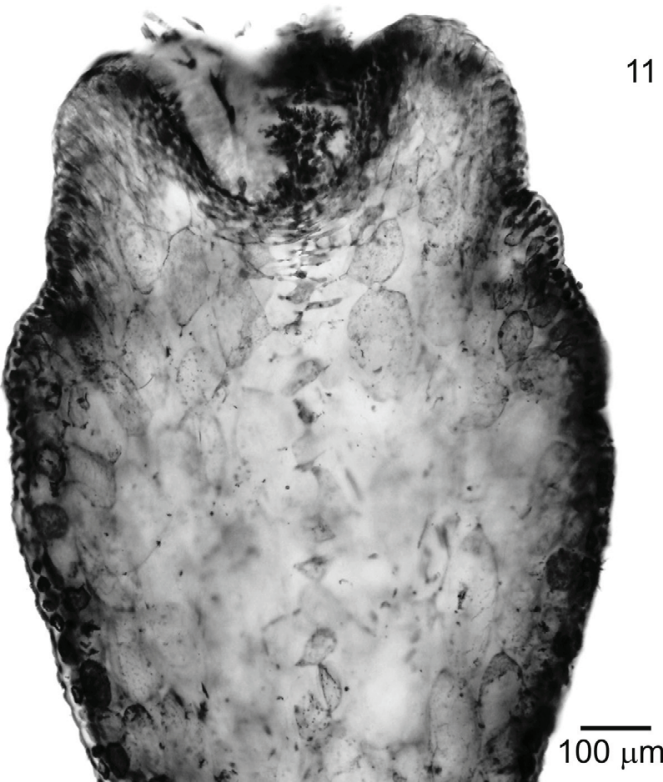

11
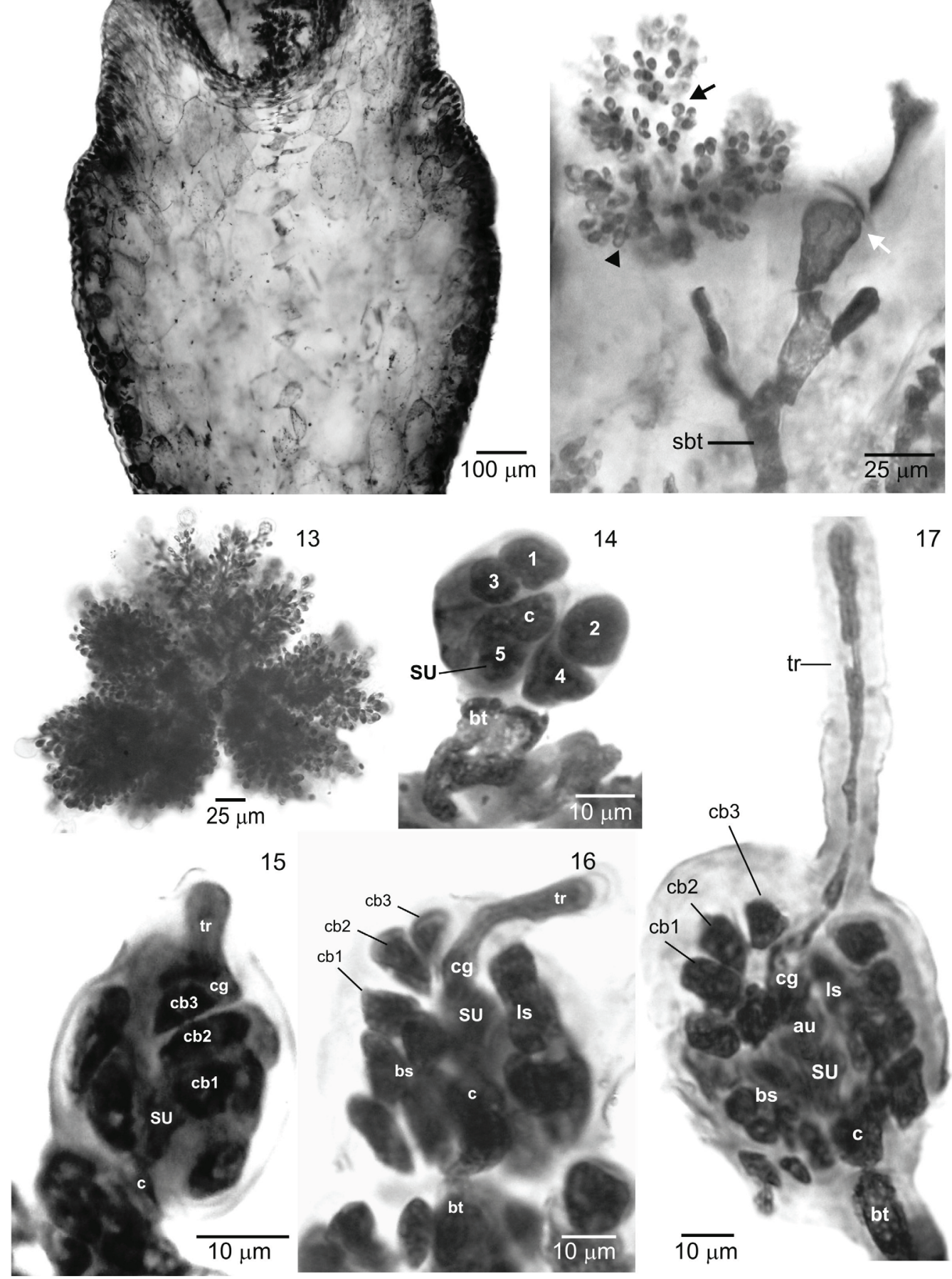

Figures 11-17. Reproductive characters. 11-13. Details of male plants. 11. Longitudinal section through a branchlet showing spermatangial branches in cup-shaped tips. 12. Detail of spermatangial branches on trichoblast with two laterals, sterile (white arrow) and spermatangial (arrowhead) branches on its suprabasal cell (sbt). Note spermatangium with an apical nucleus (black arrow). 13. Detail of trichoblast-type spermatangial branches with terminal vesicular sterile cells. 14-17. Details of female plants showing development of procarp. 14. Procarp-bearing segment with five pericentral cells, the fifth becoming the supporting cell (su) of the carpogonial branch, central cell of procarp-bearing segment (c), basal cell of trichoblast (bt). 15. Procarp before fertilization with four-celled carpogonial branch (cb), carpogonium (cg), trichogyne (tr), supporting cell (su), central cell of procarp-bearing segment (c). 16. Carpogonial branch more developed showing lateral sterile group (ls), basal sterile group (bs). 17. Carpogonial branch after fertilization showing auxiliary cell (au) formed from supporting cell (su). 


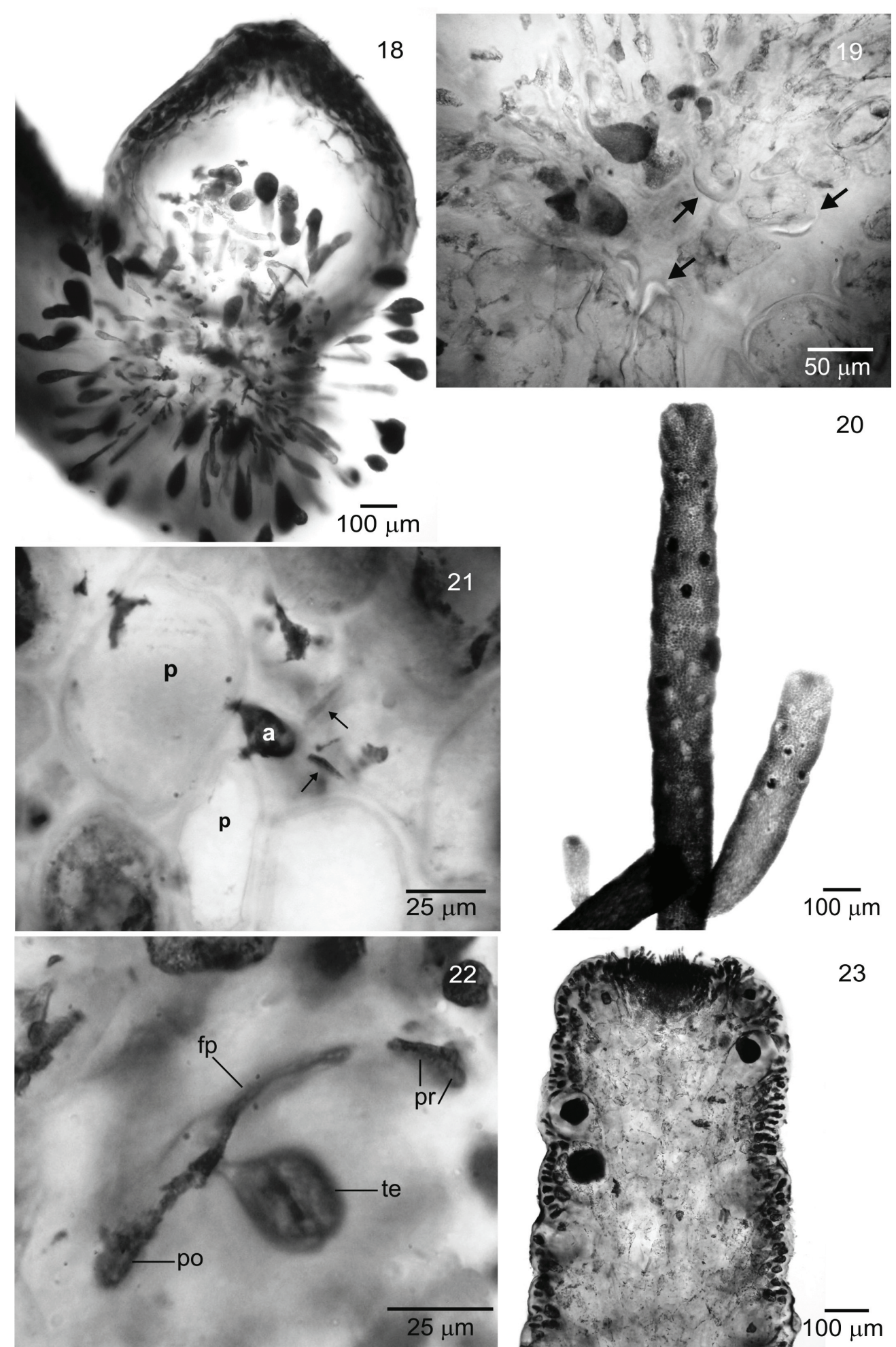

Figures 18-23. Reproductive characters. 18-19. Details of female plants. 18. Longitudinal section through a female branchlet with prominent cystocarp without a protuberant ostiole. 19. Longitudinal section of a cystocarp showing in detail its base with lenticular thickenings (arrows). 20-23. Details of tetrasporangial plants. 20. Detail of tetrasporangial branchlets. 21. Transverse section of tetrasporangial axial segment showing an axial cell (a) and two fertile pericentral cells, the third and the fourth (arrows); the other pericentral cells remain vegetative (p). 22. Detail of a fertile pericentral cell (fp) with two pre-sporangial cover cells (pr), tetrasporangium (te) and one post-sporangial cover cell (po). 23. Longitudinal section through a tetrasporangial branchlet showing parallel arrangement of the tetrasporangia. 


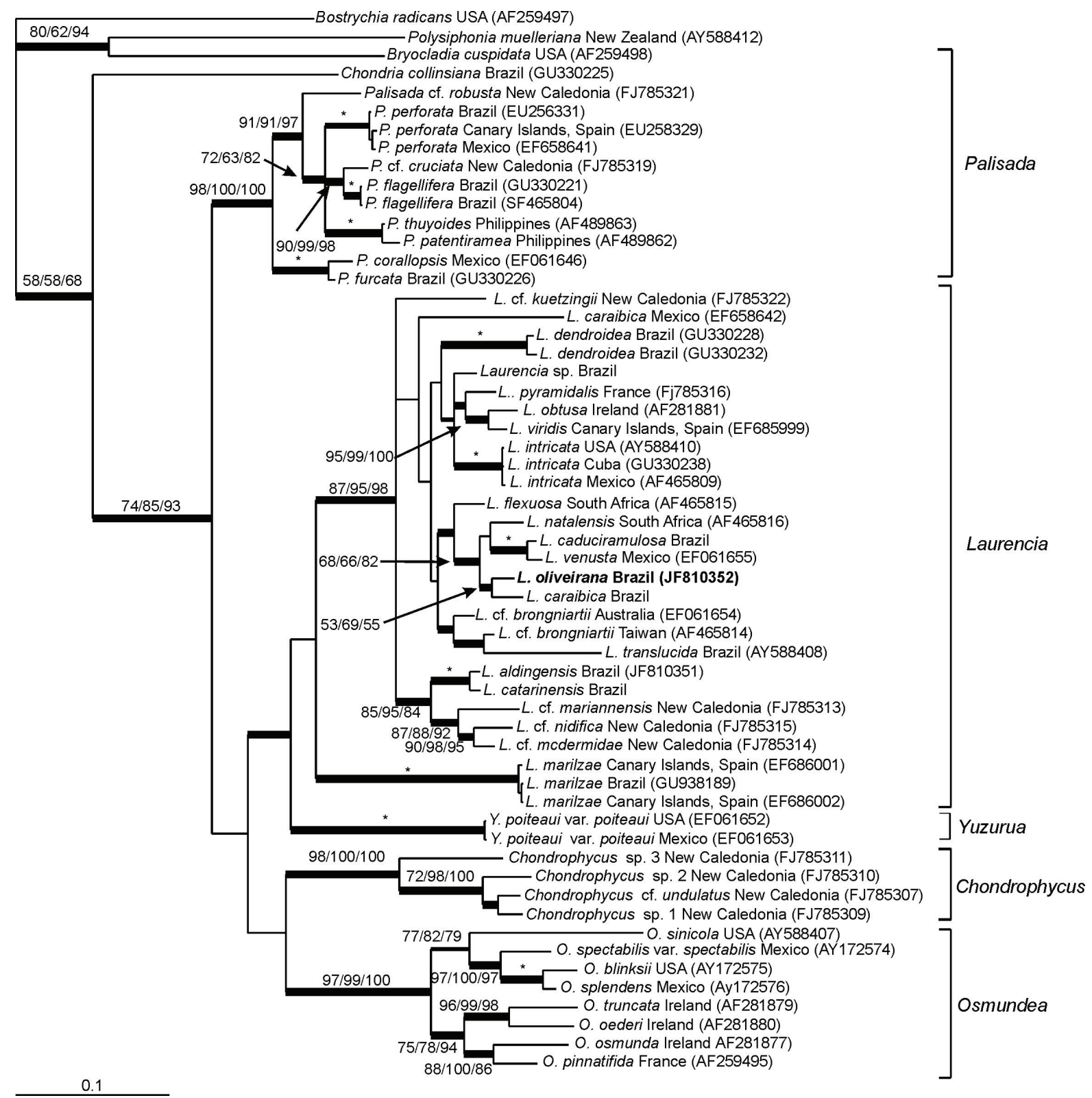

Figure 24. Consensus tree derived from Bayesian analyses of $r b c \mathrm{~L}$ sequences. The posterior probabilities, PP (when $>95 \%$ ) are shown as thicker branches. Bootstrap supports for MP/NJ (2000 replicates)/ML (1000 replicates) are shown at the nodes; *indicates bootstrap supports $=100 \%$.

with a genetic divergence of $2.3 \%$ between the two species. On the other hand, L. caraibica from Mexico positioned phylogenetically distant from L. caraibica from Brazil with a genetic divergence of $7.4 \%$.

\section{Discussion}

Laurencia oliveirana is easily recognized by its small size, sub-erect habit forming intricate cushion-like tufts, usually associated with articulated Corallinaceae algae, and predominantly unilateral pectinate branching. Lenticular thickenings, described as absent by Yoneshigue (1985), Fujii (1990) and Fujii \& Sentíes (2005), were observed for the first time for this species in tetrasporangial and female plants, mainly at the bases of cystocarps.

Laurencia oliveirana is morphologically similar to L. caraibica (type locality: Abraham Bay, Mariguana [Mayaguana], Bahamas), a species that also presents small size and intricate habit forming fastigiate mats. Laurencia caraibica was reported for the first time in Brazil from Atol das Rocas as $L$. pygmaea Weber-van Bosse (Oliveira Filho \& Ugadim, 1974; 1976). However, Fujii \& Villaça (2003), upon 
examining of the type material of L. caraibica (US 68437) and comparing it with L. pygmaea identified by Oliveira Filho \& Ugadim (1974, 1976), concluded that the Atol das Rocas material corresponded to $L$. caraibica. Edwards \& Lubbock (1983) recorded $L$. caraibica (as L. nana M.A. Howe) for the São Pedro e São Paulo Archipelago, located off the coast of northeastern Brazil.

Laurencia caraibica was considered to be distinct from L. oliveirana by the presence of abundant lenticular thickenings in the medullary cell walls and frequent anastomoses between the branches, absent in L. oliveirana (Fujii \& Villaça, 2003). The observation in this study of lenticular thickenings in L. oliveirana refutes this feature as distinguishing between these two species. However, the abundance of lenticular thickening found in L. caraibica was not observed in $L$. oliveirana. The examination of $L$. caraibica from the Atol das Rocas showed that it differs from L. oliveirana by its more delicate thallus with smaller diameter (160-210 $\mu \mathrm{m})$, presence of anastomoses between the branches, and decumbent axes, giving the thallus a dorsiventral aspect. Besides, according to Schneider et al. (2010), who reported L. caraibica from the Bermudas, this species is a delicate decumbent plant whose erect branches attach through secondary haptera to other branches or the host, a diagnostic character for this species. The analysis of $r b c \mathrm{~L}$ gene sequences obtained in this study confirmed that L. oliveirana from the type locality and L. caraibica from the Atol das Rocas are distinct species, whose genetic divergence was $2.3 \%$. On the other hand, the molecular data showed that the specimen sequenced as L. caraibica of the Mexican Caribbean (Díaz-Larrea, 2008) is a taxonomic entity distinct from $L$. caraibica described for Brazil, showing high genetic divergence (7.4\%). Mexican plants of L caraibica present a more robust thallus than those described for Brazil, reaching $5 \mathrm{~cm}$ high, with axes ranging from 0.8 to $1 \mathrm{~mm}$ in diameter, branches compressed and branching dichotomous below and irregular above, up to 3 orders of branches (Sentíes \& Fujii, 2002). A more detailed morphological comparative review of L. caraibica from Brazil and from the Caribbean Sea and related species is necessary to clarify the taxonomic position of these taxa, including a broader sampling for molecular analysis.

\section{Acknowledgements}

We are very grateful to Michael Wynne for the review of this manuscript and Joel Campos De-Paula for help with field material. This study was supported by the FAPESP (Proc. 10/50193-1, Proc. 2010/52244-2), CNPq (Proc. 473322/2008-0). Additional support was provided by the MEC the Spanish Government
Project CGL 2010-14881. VC thanks the CAPES for a PhD Student Fellowship, MTF and MCO thank the $\mathrm{CNPq}$ for Research Productivity Fellowships (Proc. 301438/2009-9 and Proc. 300748/2010-8, respectively), ASG and JDL thank the Promep-SEP (UAMI/CA/117).

\section{References}

Amado Filho GM, Horta PA, Brasileiro PS, Barros-Barreto MB, Fujii MT 2006. Subtidal benthic marine algae of the Marine State Park of Laje de Santos (São Paulo, Brazil). Braz J Oceanogr 54: 225-234.

Areces AJ, Sentíes A, Zayas CR 2003. Nuevas adiciones al género Laurencia (Ceramiales, Rhodophyta) para el archipiélago cubano. Ser Ocean 1: 104-107.

Baptista LRM 1977. Flora marinha de Torres (Chlorophyta, Xanthophyta, Phaeophyta, Rhodophyta). Bol Inst Biociências, Univ Federal do Rio Grande do Sul (Bot) 37: 1-244

Cassano V 2009. Taxonomia e filogenia do complexo Laurencia (Ceramiales, Rhodophyta), com ênfase no estado do Rio de Janeiro, Brasil. São Paulo, 328p. Tese de Doutorado, Instituto de Botânica de São Paulo.

Cassano V, De-Paula JC, Fujii MT, Teixeira VL 2008. Sesquiterpenes from the introduced red seaweed Laurencia caduciramulosa (Rhodomelaceae, Rhodophyta). Biochem Syst Ecol 36: 223-226.

Da Gama BAP, Pereira RC, Carvalho AGV, Coutinho R, Yoneshigue-Valentin Y 2002. The effects of seaweed secondary metabolites on biofouling. Biofouling 18 : 13-20.

Díaz-Larrea J 2008. Sistemática molecular del complejo Laurencia (Ceramiales, Rhodophyta) en el Caribe mexicano. Mexico D.F., 131p. Tese de Doutorado. Universidad Autónoma Metropolitana, Iztapalapa.

Edwards A, Lubbock R 1983. The ecology of Saint Paul's rocks (Equatorial Atlantic). J Zool 200: 51-69.

Erickson KL 1983. Constituents of Laurencia. In Scheuer PJ (ed.) Marine natural products: chemical and biological perspectives vol. 5. New York: Academic Press, p. 131-257.

Felsenstein J 1985. Confidence limits on phylogenies: an approach using the bootstrap. Evolution 39: 783-791.

Freshwater DW, Rueness J 1994. Phylogenetic relationships of some European Gelidium (Gelidiales, Rhodophyta) species, based on $r b c \mathrm{~L}$ nucleotide sequence analysis. Phycologia 33: 187-194.

Fujii MT 1990. Gênero Laurencia (Rhodomelaceae, Rhodophyta) no Estado de São Paulo: aspectos biológicos e taxonômicos. Rio Claro, 145p. Dissertação de Mestrado, Universidade Estadual Paulista.

Fujii MT, Sentíes A 2005. Taxonomia do complexo Laurencia (Rhodomelaceae, Rhodophyta) do Brasil, com 
ênfase nas espécies dos estados de São Paulo e do Espírito Santo. In Sentíes A, Dreckmann KM (eds) Monografías Ficológicas. II. Universidad Autónoma Metropolitana-Iztapalapa, México e Instituto de Botânica, São Paulo, Brasil, p. 69-135.

Fujii MT, Villaça R 2003. On the occurrence of Laurencia caraibica (Ceramiales, Rhodophyta) in Atol das Rocas, Brazil. Hidrobiologica 13: 33-38.

Fujii MT, Cassano V., Stein EM, Carvalho LR. 2011. Overview of the taxonomy and of the major secondary metabolites and their biological activities related to human health of the Laurencia complex (Ceramiales, Rhodophyta) from Brazil. Rev Bras Farmacogn 21: 268-282.

Gestinari LMS, Nassar CAG, Arantes PVS. 1998. Algas marinhas bentônicas da Reserva Biológica Estadual da Praia do Sul, Ilha Grande, Angra dos Reis, Rio de Janeiro, Brasil. Acta Bot Bras 12: 67-76.

Hall TA 1999. BioEdit: a user-friendly biological sequence alignment editor and analysis program for Windows 95/98/NT. Nucl Acids Symp Ser 41: 95-98.

Horta PA 2000. Macroalgas do infralitoral do sul e sudeste do Brasil: taxonomia e biogeografia. São Paulo, 301p. Tese de doutorado, Universidade de São Paulo.

Howard BM, Nonomura AM, Fenical W. 1980. Chemotaxonomy in marine algae: secondary metabolite synthesis by Laurencia in unialgal culture. Biochem Syst Ecol 8: 329336.

Huelsenbeck JP, Ronquist FR 2001. MrBayes: Bayesian inference of phylogeny. Biometrics 17: 754-755.

Joly AB 1965. Flora marinha do litoral norte do estado de São Paulo e regiões circunvizinhas. Fac Fil Ciênc Letr Univ S Paulo (Bot) 21: 1-393.

Nunes JMC 1998. Catálogo de algas marinhas bentônicas do estado da Bahia, Brasil. Acta Bot Malac 23: 5-21.

Oliveira Filho EC, Ugadim Y 1974. New references of benthic marine algae to Brazilian flora. Bol Bot Univ São Paulo 2: 71-91.

Oliveira Filho EC, Ugadim Y 1976. A survey of the marine algae of Atol das Rocas (Brazil). Phycologia 15: 4144.

Pereira RC, Teixeira VL 1999. Sesquiterpenos das algas marinhas Laurencia Lamouroux (Ceramiales, Rhodophyta). 1. Significado ecológico. Quim Nova 22: 369-374

Posada D, Crandall KA 1998. Modeltest: testing the model of DNA substitution. Bioinformatics 14: 817-818.
Salgado LT, Viana N, Andrade LR, Leal RN, Da Gama B, Attias, M, Pereira RC, Amado Filho GM 2008. Intracellular storage, transport and exocytosis of halogenated compounds in marine red alga Laurencia obtusa. J Struct Biol 162: 345-355.

Schneider CW, Lane CE, Saunders GW 2010. Notes on the marine algae of the Bermudas. 11. More additions to the benthic flora and a phylogenetic assessment of Halymenia pseudofloresii (Halymeniales, Rhodophyta) from its type locality. Phycologia 49: 154-168.

Sentíes A, Fujii, MT 2002. El complejo Laurencia (Rhodomelaceae, Rhodophyta) en el Caribe mexicano. In Sentíes A, Dreckmann KM (eds) Monografías Ficológicas. Universidad Autónoma Metropolitana - Iztapalapa y Red Latinoaméricana de Botánica, p. 121-192.

Swofford DL 2002. PAUP*: phylogenetic analysis using parsimony (*and other methods), version 4. Sinauer Associates, Sunderland, MA, USA.

Tsuda RT, Abbott IA 1985. Collecting, handling, preservation, and logistics. In Littler MM, Littler DS (eds) Handbook of phycological methods, vol. 4. Ecological field methods: macroalgae. Cambridge University Press, Cambridge, UK. p. 67-86.

Wynne MJ 2011. A checklist of benthic marine algae of the tropical and subtropical western Atlantic: third revision. Nova Hedwigia Beih 140: 1-166.

Yoneshigue Y 1985. Taxonomie et ecologie des algues marines dans la region de Cabo Frio, (Rio de Janeiro), Brésil. Marseille, France, 466p. Tese de Doutorado, Faculte des Sciences de Luminy, Uníverisité d' Aix-Marseille II.

Young DN, Howard BM, Fenical W 1980. Subcellular localization of brominated secondary metabolites in the red alga Laurencia snyderae. J Phycol 16: 182185.

\section{*Correspondence}

Valéria Cassano

Universidade de São Paulo, Instituto de Biociências, Departamento de Botânica

Rua do Matão, 277, 05508-900 São Paulo, Brazil.

vcassano@usp.br

Tel. $+55113091-7544$

Fax: +55 $113091-7547$ 